\title{
Insecurities of the Workers in the Informal Enterprises: A Study of West Bengal in Comparison to Kerala
}

\author{
Joyita Roy Chowdhury ${ }^{1, *}$ \\ ${ }^{1}$ Dept. of Economics, University of Utah, Salt Lake City, Utah, UT-84112, USA \\ *Correspondence: Dept. of Economics, University of Utah, OSH, Rm-343, 260 C. Central \\ Campus Drive, Salt Lake City, Utah, UT-84112, USA. Tel: 1-801-227-4666 E-mail: \\ joyita.roychowdhury@utah.edu
}

Received: July 21, 2014 Accepted: August 27, 2014 Published: September 24, 2014

doi:10.5296/rae.v6i3.6005 URL: http://dx.doi.org/10.5296/rae.v6i3.6005

\begin{abstract}
In the present study we have used the National Sample Survey (NSS) sixty-sixth round (2009-10) unit level data to analyze the various forms of insecurity faced by the workers in the informal sector enterprises of West Bengal and Kerala. The methodological framework of seven forms of insecurities developed by Standing $(1999,2008)$ is used in the present study. Given the fact that both West Bengal and Kerala are pro-labour states, we try to investigate the differences in the status of the informal workers within the framework of seven forms of insecurities. In a few cases observations from all-India data are added to the entire analysis of comparison between the two states.

The analysis finds out that the workers in the informal enterprises irrespective of which state they belong to do not enjoy any employment security (written job contract) and work security (paid leave or social security benefits). In a few cases the observations obtained in Kerala differ from that of West Bengal particularly with respect to skill security. A large number of casual workers in West Bengal are illiterates which have also reduced their access towards obtaining vocational training. The lack of training increases the risk of getting insecure jobs. Another important aspect of vulnerability of the workers is the social groups to which they belong. With respect to income security the condition of the informal workers in West Bengal are worsened as well as they have low collective strength which further accentuates the work related insecurities.
\end{abstract}

Keywords: Informal labour; work-related insecurity; West Bengal; Kerala; India

JEL Classification: J46, J31, J33, C010 


\section{Introduction}

In the face of increased competitiveness or flexibilisation of employment, it is widely acknowledged that labour legislation has failed to provide enough protection to the workers. The informal sector workers are the worst hit due to their particular mode of employment. Thus the issue of labour security needs to be addressed for the informal workers particularly for them who are outside the standard employer employee relationship. The workers in the informal economy are exposed to various forms of risks that could be structural or random shock (Unni and Rani, 2002b). The random shocks that hit the households from time to time occur in the form of illness, loss of a job, death of an earning member etc. The other source of insecurity resulting from the structural features of the household remains constant over a period of time. These include gender, social group, age, marital status and ownership of assets. An important structural feature that affects the informal workers is the activity status that is whether they are engaged in salaried job or work as casual worker or is self-employed (Unni and Rani, 2002b).

In the present study we have used the National Sample Survey (NSS) sixty-sixth round (2009-10) unit level data to analyze the various forms of insecurity faced by the workers, particularly the workers in the informal sector enterprises. At various stages of the study the NSS report on 'Informal Sector and Conditions of employment in India', 66 ${ }^{\text {th }}$ round (2009-10) is also used for the purpose of analysis. The methodological framework of seven forms of insecurities developed by Standing $(1999,2008)$ is used in the present study. Our primary focus rests on the workers employed in the nonagricultural informal enterprises of West Bengal and Kerala; the analysis in a few cases also extends to include the rural sector as well. Both Kerala and West Bengal are pro-labour states and hence have implemented protectionist measures. Given the fact that both West Bengal and Kerala are pro-labour states, we try to investigate the differences in the status of the informal workers within the framework of seven forms of insecurities. In a few cases observations from all-India data are added to the entire analysis of comparison between the two states.

We analyze the working conditions of the workers in the informal enterprises with respect to a few attributes such as the type of job contract, eligibility for paid leave and availability of social security benefits. In case of self-employed workers we analyse the qualitative aspects of employment like nature of employment, presence of trade unions and their perception about the remuneration from self employment. We have analyzed the insecurities of the workers in terms of their principal activity status (Note 1) as the activity status forms an important source of insecurity for the workers. While performing the analysis with the unit level data we have followed the enterprise based concept of NSSO to divide the non-agricultural enterprises into 'Informal sector enterprises' and 'All types of enterprises'. We have used the NCEUS(Note 2) definition which defines the unorganized or informal sector as the one consisting of 'all unincorporated private enterprises owned by individuals or households engaged in the sale and production of goods and services operated on a proprietary or partnership basis and with less than ten total workers.'. 
The present chapter is organized as follows: Section 2 discusses the informal sector enterprise. The next section, Section 3 deals with the concept of social security for the workers which are addressed due to the existence of various forms of insecurities. Section 4 analyses the seven forms of insecurities of the workers located in the nonagricultural informal enterprises of West Bengal and Kerala and section 5 concludes.

\section{Understanding the informal sector enterprises}

The informal workers form a heterogeneous group. According to the NSS sixty-sixth round (2009-10), the workers engaged in the unincorporated enterprises, proprietary and partnership type of enterprises constitute the informal sector enterprises. The proprietary and partnership type of enterprises are together termed as P\&P enterprises. In NSS surveys four types of informal sector enterprises are described: proprietary male, proprietary female, partnership with owners from the same household and partnership with owners from different households.

The proprietary type of ownership is the one which has single owner and the partnership enterprise consists of two or more owners. Following the guideline of 15th International Conference of Labour Statisticians (ICLS), the informal sector is defined as the production units which operate at a low level of organization with no division between labour and capital and large scale casualization of the labour relations. The workers are divided according to their activity or employment status. The three broad statuses of employment in the informal enterprises are self employment, regular wage and casual labour engaged in works other than public works. The self employed workers are further classified into own account workers, employers and those engaged in unpaid family work. The own account workers are those who operated their business with one or more partners but without hiring any labour. The employers run their enterprises with one or few partners and hired labour. The unpaid family workers are those self-employed persons who do not receive any regular wage for their employment and work part-time or full-time.The casual workers are engaged in wage employment whereas the income of the self-employed workers is not wages. The income of the self-employed workers is the residue obtained by deducting all sort of expenditures from the total income generated from the business activity. The boundary between the employer and the employees is non-existent in case of the self-employed workers. The employees are classified into categories: the wage employees who are dependent on the employers for all inputs of production and the other category form the non-wage employees who are independent workers.

\section{Concept of social security: methodological framework}

Standing (2008) defines security as the ability of an individual to survive, reproduce and develop under conditions of adequate support system such that to promote his capabilities. According to him the security agenda should be such as to enable individuals to cope with risks, uncertainties, hazards and shocks irrespective of their socio- economic status. ILO has 
defined social security as:

The protection which society provides for its members, through a series of public measures, against the economic and social distress that otherwise would be caused by the stoppage or substantial reduction in earnings resulting from sickness, maternity, employment injury, unemployment, invalidity, old age and death; the provision of medical care; and the provision of subsidies for families with children [quoted in Jhabvala (1998)].

Thus ILO's concept of social security programme is a comprehensive one aimed at protecting the workers from risks and promoting income security to cope up with the adversities. Dreze and Sen (2004) have also developed a broader concept of social security meant to prevent deprivation of the workers and providing them social means to prevent deprivation. The two important forms of social security are promotion and protection. The promotional measures are the ones that help the poor expand their basic capabilities and the protective measures aim at protection against vulnerabilities. The protective aspects are equated with support led social security and promotional aspects are equated with growth mediated social security [Dreze and Sen (1989) quoted in Kannan and Francis (2001)].

The notion of labour security has emerged in the post war period of welfare state and during the period of state socialism in Soviet Union and Eastern Europe where the models emphasized the values of labour. In social democracy the workers are compensated for the low wages and the welfare state administered redistributive justice (Sen and Dasgupta, 2009). Thus the idea of labour security was embedded in the social structure. But later on in the era of market led capitalism the forces of globalization has ensured free mobility of capital and labour being dictated in terms of capital. According to Polanyi, the era of disembeddedness has led to mass insecurity and chronic inequality (Standing, 2008). The seven vital forms of labour insecurity observed by Standing (1999) are:

(i) Income security

(ii) Labour Market security

(iii) Employment security

(iv) Job security

(v) Work security

(vi) Skill reproduction security

(vii) Representation security

According to Standing (2008), the two important forms of security are income security and representation security; the status of labour in terms of income security is judged through the fact that whether the workers receive the stipulated level of minimum wages. The representation security deals with the existence of trade unions and the membership of the workers in a trade union that is linked to the collective bargaining strength of the workers. 


\section{Analytical aspects: forms of insecurities among the workers in informal enterprises}

In order to study the forms of insecurities of the workers in the informal sector enterprises we try to build a comparison between Kerala and West Bengal. Kerala has a higher level of social sector expenditure compared to West Bengal which has led it to divert a significant proportion of its budgetary resources towards financing social security.

The present essay is an attempt to bring into foreground the various forms of insecurities of workers employed in the nonagricultural informal enterprises following the methodology proposed by Standing. We have tried to keep the various forms of insecurities, as far as possible, mutually exclusive. We first start with income security, the most important form of security.

\subsection{Income security}

The most important aspect of economic security of households is the income security, a crucial indicator of welfare of an individual. The income security is defined by ILO (2004; p.55) as consisting of an adequate level of income which is fair relative to the income of other individuals and can fulfill the needs and assure a level of compensation at the time of crisis. The income security of the workers is understood through the following indicators:

\subsubsection{Minimum wages}

The traditional form of judging income security is through the formation of minimum wage legislation. The statutory fixed wage constitutes the income security of the workers such that if the earnings fall below the given level the workers become vulnerable to various risks. The minimum wage legislation is important in fixing the wages of skilled, unskilled and semiskilled workers employed in the informal enterprises. The fixation of minimum wage is basically a labour market institution. The primary objective of fixing the minimum wage is to improve the standard of living of the lowest paid workers and those who are least able to form a collective strength to voice their interests. Thus the principle of fixing minimum wage is not connected to the revenue earned by the worker rather it is solely based on the status of the wage earner (Eyraud and Saget, 2005).

Each of the states in India has defined an institutionally fixed minimum wage stipulated for the workers and the country as a whole has set up a national minimum wage that is considered as the basic standard. The Minimum Wages Act 1948 fixes the minimum wages payable to any person who is in an employment specified in the schedule. The Minimum Wages Act(Note 3) is applicable to 'every person who is employed for hire or reward to do any work, skilled or unskilled, manual or clerical, in an employment specified in the schedule and in respect to which minimum rates of wages have been fixed' (NCEUS, 2007). The range of minimum wages for unskilled workers for all the states is shown in appendix table 1 . Among the states West Bengal has recorded one of the lowest minimum wages among the states and the range lies even below the centrally fixed range of minimum range.

The second most important component that needs to get discussed is the actual earnings of the workers. The average daily wage is compared to assess the status of labour in terms of 
income security.

\subsubsection{Average daily wages}

Here we compare the average daily earnings of the regular and casual workers in the informal enterprises of West Bengal with Kerala. It reflects the extent of income security associated with the status of employment. The average wage of the casual workers in informal enterprises of West Bengal is low compared to Kerala and all the states (see figure 1). Both the rural and urban wage for the casual workers in Kerala is high compared to the national figure. When compared with the national figures, West Bengal records substantially low average wage earnings for the casual workers in the informal sector enterprises.

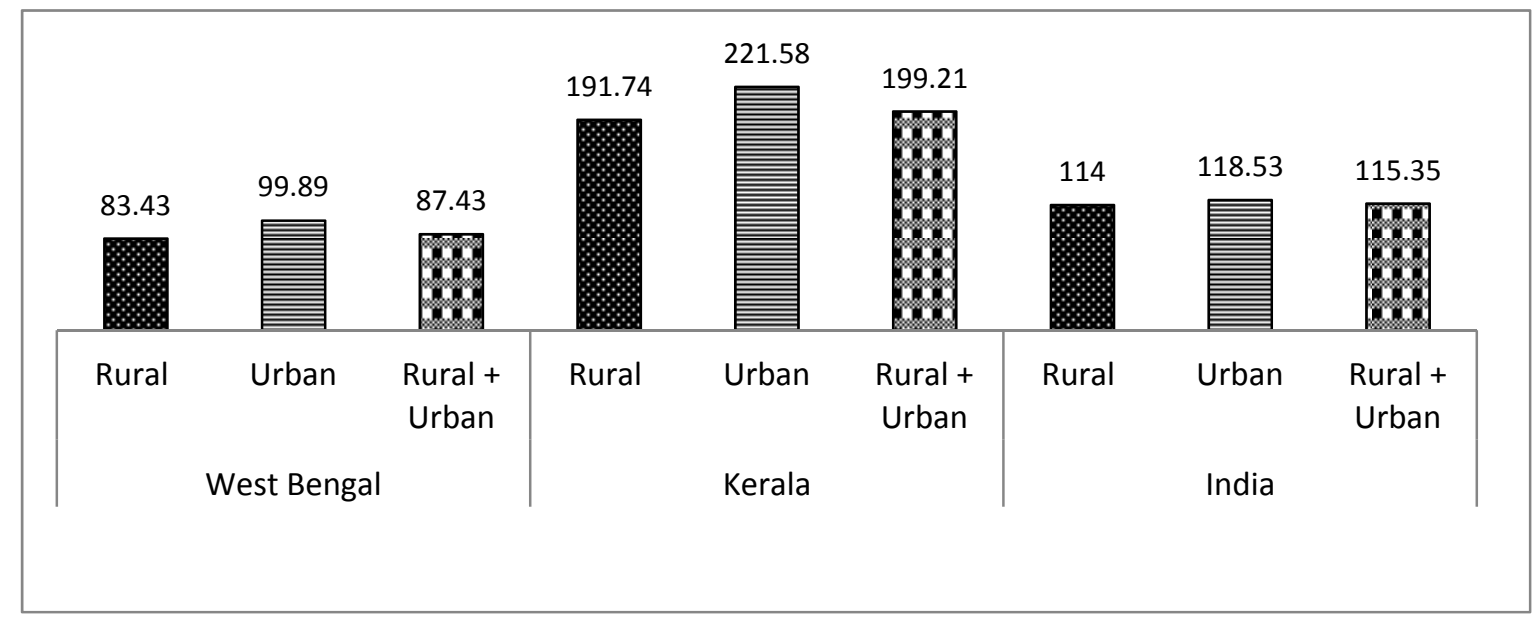

Source: Informal Sector and Conditions of employment in India, July 2009- June 2010, $66^{\text {th }}$ round, NSSO: Report No. 539. Note: PS is Principal activity status and SS is Subsidiary activity status

Figure 1. Average wage/salary earnings (Rs.) per day for the casual workers according to (PS+SS) in informal enterprises

In case of regular workers in the nonagricultural informal enterprises we observe the same pattern that is both the urban and rural wage in Kerala is relatively higher (see figure 2). Another interesting fact is that there is no significant wage disparity between the regular and casual workers in the urban informal enterprises of Kerala. Whereas in the rural areas of Kerala the daily average wage of the casual workers is comparatively higher than the regular workers. It is an exception to the national data on average wage earnings where the regular workers earn higher wages compared to the casual workers in the rural areas. This particular observation is common to rural West Bengal as well. It implies that the income security of the casual workers in the rural areas of Kerala is well strengthened with relatively higher average earnings. 


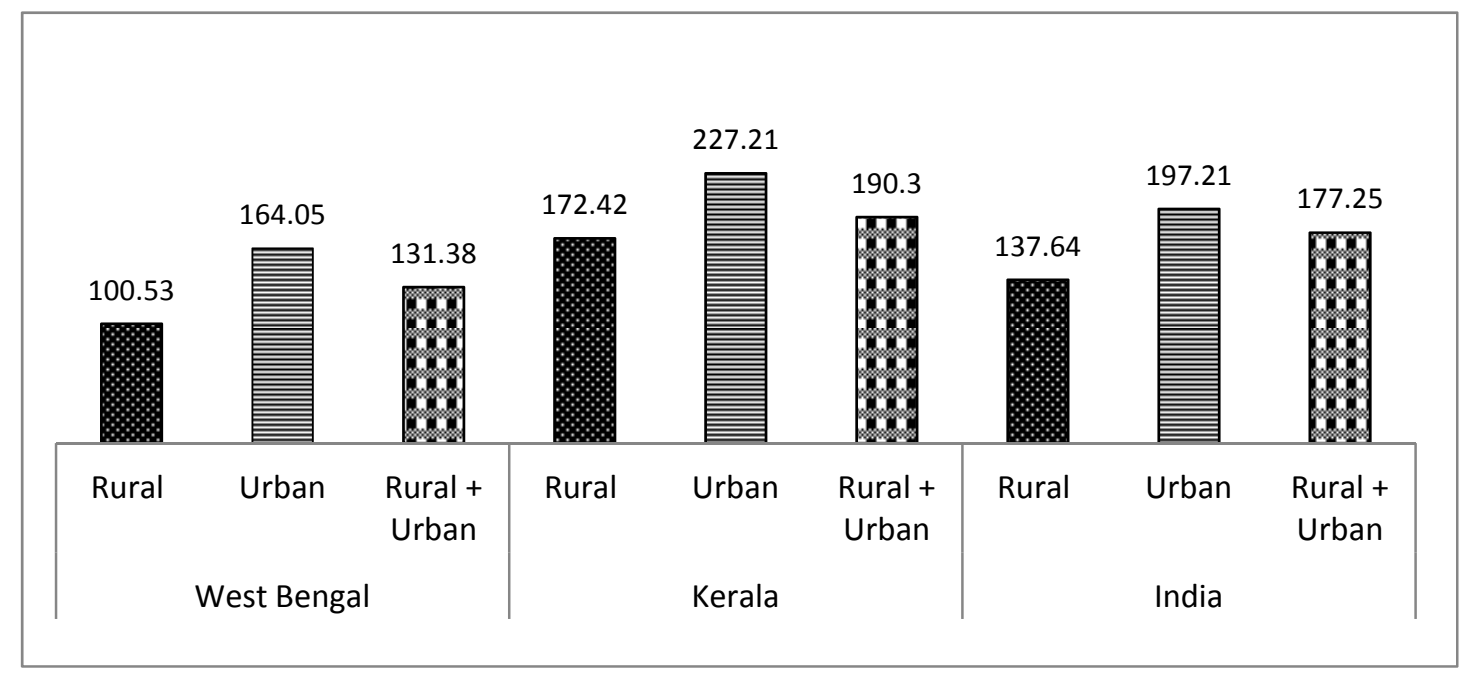

Source: Informal Sector and Conditions of employment in India, July 2009- June 2010, 66 ${ }^{\text {th }}$ round, NSSO:

Report No. 539. Note: PS is Principal activity status and SS is Subsidiary activity status

Figure 2. Average wage/salary earnings (Rs.) per day for the regular workers according to (PS+SS) in informal enterprises

Kerala has a high unemployment rate but lower income insecurity for the workers in the informal enterprises compared to West Bengal. According to International Labour Organization (ILO), the unemployment rate is one the standard indicators of labour market security (ILO, 2004, p.113). The comparison between Kerala and West Bengal shows that unemployment rate is higher in Kerala which implies that in the relatively backward states like West Bengal the unemployment figures (according to principal status) are low due to the presence of a large number of working poor (see table 1). The reverse is true for the developed state with higher social sector expenditure as people prefer remaining unemployed than getting absorbed in low paid occupations.

Table 1. Unemployment rates (per 1000) according to PS for Kerala and West Bengal

\begin{tabular}{lcccccc}
\hline & \multicolumn{3}{c}{ West Bengal } & \multicolumn{3}{c}{ Kerala } \\
\cline { 2 - 7 } Sector & Male & Female & Persons & Male & Female & Persons \\
\hline Rural & 24 & 47 & 27 & 38 & 210 & 90 \\
Urban & 37 & 109 & 49 & 34 & 198 & 83 \\
\hline
\end{tabular}

Source: NSSO Report No. 537, $66^{\text {th }}$ round, 2009-10.

\subsection{Labour market security}

The serious threat towards the informal sector workers is employment at low levels of income. Being poor they cannot afford to remain unemployed and are forced to take up any kind of jobs to meet subsistence needs (Unni and Rani, 2002a). According to the NSS report(Note 4) on 'Informal sector and Conditions of Employment in India (2009-10)', the proportion of regular workers is comparatively lower in both the states. We find that the proportion of female regular workers is lower in West Bengal compared to Kerala (see table 2). In the rural areas of West Bengal relatively higher proportion of male and female workers are engaged in the informal enterprises compared to Kerala. In the urban areas higher number of female 
workers is engaged in the informal enterprises of West Bengal than Kerala.

Table 2. Proportion (per 1000) of informal workers* among workers** (PS+SS) engaged in agricultural and non-agricultural sectors for different status in employment in West Bengal and Kerala

\begin{tabular}{lcccccccc}
\hline \multirow{2}{*}{ Activity status } & \multicolumn{3}{c}{ West Bengal } & \multicolumn{3}{c}{ Kerala } \\
\cline { 2 - 9 } & \multicolumn{2}{c}{ Rural } & \multicolumn{2}{c}{ Urban } & \multicolumn{2}{c}{ Rural } & Urban \\
\cline { 2 - 9 } & Male & Female & Male & Female & Male & Female & Male & Female \\
\hline Own account worker & 962 & 906 & 973 & 980 & 982 & 989 & 962 & 942 \\
Employer & 502 & - & 979 & 1000 & 1000 & 1000 & 1000 & 1000 \\
Unpaid family worker & 955 & 965 & 945 & 1000 & 1000 & 1000 & 1000 & 1000 \\
Sub total & 957 & 919 & 970 & 986 & 986 & 992 & 969 & 960 \\
Regular & 559 & 155 & 336 & 129 & 460 & 361 & 397 & 293 \\
Casual labour other than & & & & & & & & \\
public works & 837 & 769 & 762 & 325 & 862 & 642 & 893 & 672 \\
Total & 847 & 779 & 695 & 595 & 809 & 662 & 759 & 560 \\
\hline
\end{tabular}

Source: Informal Sector and Conditions of employment in India, July 2009- June 2010, 66 ${ }^{\text {th }}$ round,

NSSO:

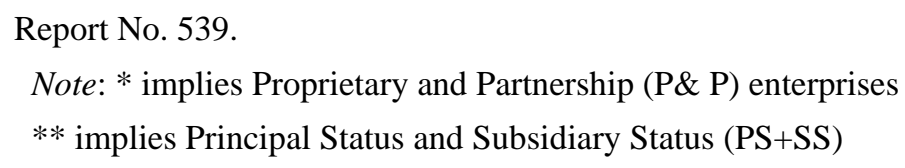

Hence a large proportion of workforce is engaged as casual and self employed workers with no stable employment contract indicate labour market insecurity. The workers in the informal enterprises not only engage themselves in low paid occupations but are subject to insecure employment.

\subsection{Employment security: insecure employment}

The concept of employment security is subjective in the sense that employment can be considered as a factor determining self esteem. This is the recognition aspect where the quality of employment gives a person the recognition of being engaged in an occupation that is considered to be worthwhile (Sen, 1975).

Employment security is the protection against arbitrary loss of any income earning activities. It has both subjective and objective elements. The objective indicator of employment security is the presence of regular or stable employment contracts to prevent arbitrary dismissal. The other indicator is the subjective expectation that the person can retain his employment (ILO, 2004). It is presumed that generally the regular wage or salary earners, a small proportion of the total workforce enjoy strong protection against arbitrary dismissal due to the presence of regulatory safeguards. The casual workers by nature of their employment are without any form of written contract (see table $3 \&$ table 4 ). They suffer from employment insecurity due to the type of job contract. The absence of job contract for the casual workers is a general phenomenon for the workers in the informal enterprises. With respect to the regular wage earners in the rural informal enterprises, the incidence of no written job contract is common 
in both West Bengal and Kerala. In the absence of job contract the workers can be easily dismissed from work.

Table 3. Workers in the rural non-agricultural informal sector (P \& P) enterprises with no job contract

\begin{tabular}{lcccccc}
\hline & \multicolumn{2}{c}{ West Bengal } & \multicolumn{2}{c}{ Kerala } & \multicolumn{2}{c}{ All India } \\
\cline { 2 - 7 } Job contract & Regular & Casual & Regular & Casual & Regular & Casual \\
\hline No written job contract & 89.78 & 99.33 & 91.84 & 99.17 & 91.72 & 96.94 \\
Written for 1 year or less & 0 & 0.67 & 2.72 & 0.07 & 1.88 & 1.06 \\
Written for more than1year & 4.88 & 0 & 1.8 & 0 & 1.13 & 0.01 \\
Written more than 3 year & 5.34 & 0 & 3.64 & 0.77 & 5.27 & 0.31 \\
Method of Payment & & & & & & \\
Piece rate payment & 6.51 & 14.25 & 2.13 & 9.1 & 3.84 & 8.3 \\
Regular monthly salary & 68.72 & 6.12 & 58.59 & 2.26 & 78.86 & 4.69 \\
Regular weekly payment & 19.44 & 19.75 & 15.73 & 11.63 & 8.62 & 16.68 \\
Daily payment & 4.5 & 56.6 & 19.31 & 73.57 & 5.87 & 65.64 \\
Others & 0.83 & 3.28 & 4.25 & 3.43 & 2.82 & 4.24 \\
\hline
\end{tabular}

Source: NSS 66 ${ }^{\text {th }}$ Round (2009-10), Employment - Unemployment Survey, Author's calculation

Note: $\quad$ All the figures indicate percentages

In case of the urban non-agricultural informal enterprises the pattern does not differ from that of the rural informal enterprises. The casual workers are at higher employment risk with no written form of job contract.

Table 4. Workersin the urban non-agricultural informal sector ( $\mathrm{P} \& \mathrm{P}$ ) enterprises with no job contract

\begin{tabular}{lcccccc}
\hline & \multicolumn{2}{c}{ West Bengal } & \multicolumn{2}{c}{ Kerala } & \multicolumn{2}{c}{ All India } \\
\cline { 2 - 7 } Job contract & Regular & Casual & Regular & Casual & Regular & Casual \\
\hline No written job contract & 88.44 & 96.56 & 92 & 99.72 & 92.77 & 98.4 \\
Written for 1 year or less & 1.34 & 1.7 & 2.01 & 0.28 & 1.26 & 1.03 \\
Written for more than1year & 0.42 & 0 & 2.04 & 0 & 1.43 & 0 \\
Written more than 3 year & 9.8 & 1.73 & 3.94 & 0 & 4.54 & 0.56 \\
Method of Payment & & & & & & \\
Piece rate payment & 5.07 & 6.75 & 3.06 & 9.51 & 4.08 & 10.21 \\
Regular monthly salary & 76.38 & 12.33 & 77.08 & 2.84 & 84.68 & 9.6 \\
Regular weekly payment & 13.4 & 22.83 & 9.01 & 10.88 & 7.78 & 22.35 \\
Daily payment & 4.17 & 52.85 & 6.33 & 74.58 & 2.41 & 53.58 \\
others & 0.97 & 5.25 & 4.52 & 2.2 & 1.05 & 4.26 \\
\hline
\end{tabular}

Source: NSS 66 ${ }^{\text {th }}$ Round (2009-10), Employment - Unemployment Survey, Author's calculation

Note: $\quad$ All the figures indicate percentages

Another source of employment insecurity for the casual workers arises due to the method of payment. The majority of the casual workers in the rural informal enterprises have received daily payment, and a very few of them have earn on regular basis. The daily payment of 
wages to the casual workers is relatively higher in the state of Kerala. The piece rate system is a prevalent means of payment particularly in the rural areas. The presence of regular monthly salary is a predominant feature among the regular salaried workers but the workers are reported to have no written job contract. The presence of salary on regular monthly basis ensures a minimum level of security for the salaried workers. The casual workers earn on daily basis with verbal employment contract. The daily payment system increases their risk at job.

Another important factor determining the quality of employment is the location of the workplace. The location of workplace has been categorized as the one with fixed location and the other with no fixed location of workplace (see table 5).

Table 5. Percentage of workers in the informal enterprises with no fixed location of work

\begin{tabular}{lcccccc}
\hline \multirow{2}{*}{ Employment status } & \multicolumn{2}{c}{ West Bengal } & \multicolumn{2}{c}{ Kerala } & \multicolumn{2}{c}{ All India } \\
\cline { 2 - 7 } & Rural & Urban & Rural & Urban & Rural & Urban \\
\hline Own Account worker & 82.73 & 85.41 & 62.3 & 54.38 & 61.89 & 70.61 \\
Employer & - & & - & 0.86 & 0.03 & 0.44 \\
Unpaid family worker & 4.37 & 0.74 & 14.52 & 1.5 & 4.98 & 6.15 \\
Regular employee & 1.46 & 3.04 & 2.68 & 1.2 & 10.56 & 8.5 \\
Casual labour & 11.43 & 10.81 & 20.5 & 42.06 & 22.55 & 14.3 \\
\hline
\end{tabular}

Source: NSS 66 ${ }^{\text {th }}$ Round (2009-10), Employment - Unemployment Survey, Author's calculation

Note: All the figures indicate percentages

Majority of the own account workers in the informal enterprises of both rural and urban West Bengal have no fixed place to work. A relatively few percentage of workers have fixed location such as they work in their own dwelling units, employer's dwelling unit or enterprise and streets with fixed location. Thus the own account workers face insecurity in terms of no definite location of workplace. A large number of casual workers in Kerala particularly in the urban areas lack fixed location of work.

\subsubsection{Employment security of the self employed workers}

The self employed workers form a heterogeneous category consisting of own account workers, employers and unpaid family workers. These sub-categories within the self employment are largely dictated by work status. The own account workers form the largest category among the self employed workers. They work on their own using their labour power and often work for longer hours to earn a living which the Russian economist Chayanov has termed as 'self exploitation' while referring to the Russian peasantry of the nineteenth century. The second category is that of the 'unpaid family worker' who do not receive any independent remuneration while they contribute to the family income. The third category is that of the employer who employs at least one hired labour (ILO, 2002)(Note 5).

Since the self employed workers do not have employment contract as there is no definite employer-employee relationship, their security depends on the availability of raw materials, credit and other inputs required for production. The self-employed workers with no definite employer-employee relationship arrange the raw materials for production by own or have to 
depend on the employer for the same. In Kerala relatively higher number of own account workers (51 percent) in the rural informal enterprises arrange the inputs for production and credit by their own to expand the economic activities. The pattern is similar in rural informal enterprises of India where the own account workers and the employers arrange their inputs by their own efforts. In the urban informal enterprises of Kerala the self dependence among all the categories of self employed workers is even higher. With respect to West Bengal both in the rural and urban informal enterprises the own account workers show comparatively higher dependence on the enterprises for the supply of credit and other raw materials of production (see table 6 and table 7). The employer category in the rural informal sector of West Bengal depends on the enterprises for the supply of raw materials. The employer section subcontract the works obtained from the enterprise to the workers living in the rural areas. This happens in 'zarri' (embroidery) works where the middlemen have direct relationship with the enterprise wherefrom they obtain the work contracts. The middlemen or the employer distributes the work contracts and raw materials among the workers who do not have direct relationship with the enterprise.

Table 6. Sources of credit/raw materials for the self employed workers in the rural non-agricultural informal sector enterprises

\begin{tabular}{|c|c|c|c|c|c|c|c|c|c|}
\hline \multirow[b]{2}{*}{$\begin{array}{l}\text { Source of } \\
\text { credit/ raw } \\
\text { materials }\end{array}$} & \multicolumn{3}{|c|}{ West Bengal } & \multicolumn{3}{|c|}{ Kerala } & \multicolumn{3}{|c|}{ All India } \\
\hline & $\begin{array}{l}\text { Own } \\
\text { account } \\
\text { worker }\end{array}$ & Employer & $\begin{array}{l}\text { Unpaid } \\
\text { family } \\
\text { worker }\end{array}$ & $\begin{array}{l}\text { Own } \\
\text { account } \\
\text { worker }\end{array}$ & Employer & $\begin{array}{l}\text { Unpaid } \\
\text { family } \\
\text { worker }\end{array}$ & $\begin{array}{l}\text { Own } \\
\text { account } \\
\text { worker }\end{array}$ & Employer & $\begin{array}{l}\text { Unpaid } \\
\text { family } \\
\text { worker }\end{array}$ \\
\hline $\begin{array}{l}\text { Own } \\
\text { arrangement }\end{array}$ & 32.9 & 35.03 & 23.34 & 50.64 & 66.27 & 47.58 & 54.42 & 55.73 & 45.49 \\
\hline $\begin{array}{l}\text { Supplied by } \\
\text { the } \\
\text { enterprise }\end{array}$ & 67.1 & 64.97 & 76.66 & 49.35 & 30.5 & 61.13 & 45.58 & 44.28 & 54.5 \\
\hline
\end{tabular}

Source: NSS 66 ${ }^{\text {th }}$ Round (2009-10), Employment - Unemployment Survey, Author's calculation

Note: All the figures indicate percentages

Table 7. Sources of credit/raw materials for the self-employed workers in the urban non-agricultural informal sector enterprises

\begin{tabular}{|c|c|c|c|c|c|c|c|c|c|}
\hline \multirow[b]{2}{*}{$\begin{array}{l}\text { Source of } \\
\text { credit/ raw } \\
\text { materials } \\
\end{array}$} & \multicolumn{3}{|c|}{ West Bengal } & \multicolumn{3}{|c|}{ Kerala } & \multicolumn{3}{|c|}{ All India } \\
\hline & $\begin{array}{l}\text { Own } \\
\text { account } \\
\text { worker }\end{array}$ & Employer & $\begin{array}{l}\text { Unpaid } \\
\text { family } \\
\text { worker }\end{array}$ & $\begin{array}{l}\text { Own } \\
\text { account } \\
\text { worker }\end{array}$ & Employer & $\begin{array}{l}\text { Unpaid } \\
\text { family } \\
\text { worker }\end{array}$ & $\begin{array}{l}\text { Own } \\
\text { account } \\
\text { worker }\end{array}$ & Employer & $\begin{array}{l}\text { Unpaid } \\
\text { family } \\
\text { worker }\end{array}$ \\
\hline $\begin{array}{l}\text { Own } \\
\text { arrangement }\end{array}$ & 36.13 & 85.99 & 18.22 & 62.19 & 69.95 & 78.07 & 62.11 & 74.56 & 53.06 \\
\hline $\begin{array}{l}\text { Supplied by } \\
\text { the } \\
\text { enterprise }\end{array}$ & 63.88 & 14.01 & 81.78 & 37.82 & 30.06 & 21.93 & 37.89 & 25.44 & 46.94 \\
\hline
\end{tabular}

Source: NSS 66 ${ }^{\text {th }}$ Round (2009-10), Employment - Unemployment Survey; Author's calculation

Note: All the figures indicate percentages 


\section{Ml Macrothink}

Thus we can argue that the likelihood of dependence among the self employed workers is comparatively higher in West Bengal than Kerala.

The availability of credit or raw materials determine employment security of the own account workers. Though the own account workers enjoy work autonomy but suffer from employment insecurity due to lack of accessibility of credit and other inputs for production. The employment security of the self employed workers can be judged with the presence of nature of specifications and the basis of payment (see table 8 and table 9).

Table 8. Basis of payment and work specifications of self-employed workers (Rural)

\begin{tabular}{|c|c|c|c|c|c|c|c|c|c|}
\hline \multirow[b]{2}{*}{$\begin{array}{l}\text { Basis of } \\
\text { Payment }\end{array}$} & \multicolumn{3}{|c|}{ West Bengal } & \multicolumn{3}{|c|}{ Kerala } & \multicolumn{3}{|c|}{ All India } \\
\hline & $\begin{array}{l}\text { Own } \\
\text { account } \\
\text { worker }\end{array}$ & Employer & $\begin{array}{l}\text { Unpaid } \\
\text { family } \\
\text { worker }\end{array}$ & $\begin{array}{l}\text { Own } \\
\text { account } \\
\text { worker }\end{array}$ & Employer & $\begin{array}{l}\text { Unpaid } \\
\text { family } \\
\text { worker }\end{array}$ & $\begin{array}{l}\text { Own } \\
\text { account } \\
\text { worker }\end{array}$ & Employer & $\begin{array}{l}\text { Unpaid } \\
\text { family } \\
\text { worker }\end{array}$ \\
\hline Piece rate & 67.7 & 84.69 & 84.82 & 91.87 & 26.5 & 92.22 & 73.85 & 60.57 & 82.86 \\
\hline Contract basis & 32.3 & 15.31 & 15.18 & 8.13 & 73.5 & 7.78 & 26.15 & 39.43 & 17.14 \\
\hline $\begin{array}{l}\text { Type of } \\
\text { specifications }\end{array}$ & & & & & & & & & \\
\hline written & 3.09 & 0 & 1.91 & 6.38 & 17.7 & 0 & 6.53 & 35.74 & 7.38 \\
\hline oral & 95.17 & 100 & 93.99 & 90.02 & 82.3 & 93.86 & 83.09 & 63 & 82.1 \\
\hline Not known & 1.74 & 0 & 4.11 & 3.61 & 0 & 6.14 & 10.38 & 1.26 & 10.52 \\
\hline
\end{tabular}

Source: NSS $66^{\text {th }}$ Round (2009-10), Employment - Unemployment Survey, Author's calculation

Note: All the figures indicate percentages

Table 9. Basis of payment and work specifications of self-employed workers (Urban)

\begin{tabular}{lccccccccc}
\hline & \multicolumn{3}{c}{ West Bengal } & \multicolumn{3}{c}{ Kerala } & \multicolumn{3}{c}{ All India } \\
\cline { 2 - 10 } \begin{tabular}{l} 
Payment \\
\cline { 2 - 10 }
\end{tabular} & $\begin{array}{l}\text { Own } \\
\text { account } \\
\text { worker }\end{array}$ & Employer & $\begin{array}{l}\text { Unpaid } \\
\text { family } \\
\text { worker }\end{array}$ & $\begin{array}{l}\text { Own } \\
\text { account } \\
\text { worker }\end{array}$ & Employer & $\begin{array}{l}\text { Unpaid } \\
\text { family } \\
\text { worker }\end{array}$ & $\begin{array}{l}\text { Own } \\
\text { account } \\
\text { worker }\end{array}$ & $\begin{array}{l}\text { Employer } \\
\text { Unpaid } \\
\text { family } \\
\text { worker }\end{array}$ \\
\hline Piece rate & 70.27 & 46 & 85.04 & 72.34 & 59.61 & 96.3 & 74.25 & 55.4 & 86.38 \\
Contract basis & 29.73 & 54 & 14.96 & 27.66 & 40.39 & 0.37 & 25.75 & 44.7 & 13.62 \\
Type of & & & & & & & & & \\
specifications & & & & & & & & & \\
written & 5.36 & 50 & 13.27 & 6.3 & 9.14 & 0 & 12.46 & 19.4 & 14.63 \\
oral & 92.38 & 50 & 86.73 & 92.4 & 88.53 & 100 & 8063 & 75.5 & 79.55 \\
Not known & 2.26 & 0 & 0 & 1.26 & 2.33 & 0 & 6.91 & 5.13 & 5.82 \\
\hline
\end{tabular}

Source: NSS $66^{\text {th }}$ Round (2009-10), Employment - Unemployment Survey, Author's calculation

Note: All the figures indicate percentages

As we find that in the rural areas the majority of the own account workers do not have written specifications of work. About 95 per cent of the own account workers in West Bengal have verbal or oral contracts. The corresponding percentages or verbal contract are 90 percent and 83 percent in Kerala and India respectively. With regard to the basis of payment relatively larger percentage of own account workers in Kerala have piece rate payment whereas 
relatively higher percentage of own account workers in West Bengal are employed on contract basis. The involvement of workers in contractual form of employment increases their vulnerability. Nearly, 68 percent of own account workers and 84 percent of unpaid family workers receive piece rate payment in West Bengal. On the other hand in Kerala 92 percent of the own account workers and 92 percent of the unpaid family workers receive piece rate payment. In comparison to the own account and unpaid family workers a lower proportion of employers receive piece rate form of payment. The 'employer' section in West Bengal is relatively better as majority receive payment according to piece rate system. But the employers earn on contract basis in Kerala.

In the urban areas the employer section in West Bengal works under contract basis whereas in Kerala relatively more work under piece rate. The 'oral' basis of specification is a common phenomenon among the self employed workers irrespective of rural or urban location.

The aspect of employment security is closely associated with income security as the subjective perception of employment security is reduced for the casual workers. The workers with insecure employment contract that is, the casual workers are the likely ones to suffer from deprivation of non-wage benefits. The casual workers not only have lower income security but are also systematically deprived of other forms of non-wage benefits. Thus the workers with weak employment security are associated with other forms of work related insecurities such as absence of occupational safety and health regulatory measures.

\subsection{Work Security: Work entitlements}

In addition to the money income the workers are also entitled to various occupational benefits-non wage benefits such as paid leave and medical benefits. The non wage benefits form an important source of income security and are discussed under 'work security'. The work security is related to the working conditions and other facilities that promote the worker's wellbeing. The work security cover issues more than that of occupational health and safety measures and is applicable to the regular salaried and casual workers. ILO (2004) has identified the different phases of regulation relating to work security(Note 6).

In the initial phase, the measures of regulation has relied on a model of statutory regulation in which the government has passed certain laws in setting the labour standards and urging the enterprises to introduce safety departments based on the international convention and recommendation on occupational health and safety. In the second phase which is marked by the era of neo-liberalism the whole mechanism of providing protection to the worker through means of government regulation has got completely reversed. The approach to work security is then governed by market regulation which requires the government to cut their expenditure for promoting safety of the workers. The idea is that if the rules and regulations meet all the contingencies of the workers then they might develop a tendency to be careless. This gives rise to the problem of adverse selection. And if on the other hand the employers are forced to pay heavy compensation to the workers then they might develop a tendency to employ workers more under contractual agreements than the regular ones. Thus the traditional forms of work security regulation are paternalistic whereas the market regulation models create incentives for opportunism. The economic liberalization has shifted the focus from the 
strongly enforced statutory regulation to reliance on market regulation.

The work security is understood in terms of nature of contracts and availability of social security benefits(Note 7) to the regular and casual workers. The questions related to work security are mainly based on the entitlements. For instance, if the workers are not entitled to paid leave when suffering from illness, they delay medical treatment unless the illness takes an acute form. This result in large-scale absenteeism from work and eventually the particular worker suffers a job loss. The provision of social security benefits is meant to enhance the productive efficiency of workers. These benefits include PF/Pension, gratuity, health care and maternity benefits mainly targeted towards the regular workers. The PF /Pension are forms of income security during the particular period of life when the individuals become unproductive. The health care benefits support the workers during the period of illness. It is expected that the casual workers in the informal enterprises are not eligible to receive any social security benefit but an interesting fact to note is that a few percentage of regular workers in the informal enterprises receive Provident Fund (PF)/ Pension, health care and maternity benefits. With regard to the allowance of social security benefit, majority of the regular wage workers in both rural and urban West Bengal are deprived of the benefit. This feature is common to Kerala and all India where a large proportion of regular workers in the nonagricultural informal enterprises do not receive any social security benefit (see table 10). With regard to receipt of paid leave(Note 8) the condition of the regular workers in the informal enterprises is no better.

A very small proportion of the casual workers earn regular monthly salary and majority of them either have daily payment or piece rate payment. Thus they are not entitled to any form of social security benefit. Though the regular workers earn regular monthly salary but are not subject to receive non-wage benefits.

Table 10. Work entitlements of the regular and casual workers in the non-agricultural informal enterprises

\begin{tabular}{lcccccc}
\hline & \multicolumn{2}{c}{ West Bengal } & \multicolumn{2}{c}{ Kerala } & \multicolumn{2}{c}{ All India } \\
\cline { 2 - 7 } Rural & Regular & Casual & Regular & Casual & Regular & Casual \\
\hline No social & & & & & & \\
security benefit & 98.98 & 98.72 & 95.01 & 99.5 & 94.46 & 98.98 \\
No paid leave & 76.52 & 96.46 & 84.9 & 99.6 & 84.3 & 98.45 \\
Urban & & & & & & \\
No social & & & & & & \\
security benefit & 90.12 & 99.16 & 86.62 & 99.72 & 92.7 & 99.3 \\
No paid leave & 62.14 & 98.64 & 76.27 & 99.22 & 81.59 & 97.84 \\
Source: NSS 66 & Round (2009-10), Employment - Unemployment Survey, Author's calculation
\end{tabular}

Note: All the figures indicate percentages

As we have discussed that the workers in the informal enterprises are deprived of various non-wage benefits; the condition of the casual workers is far more miserable as they are not only deprived of non wage entitlements but have insecure employment status by the nature of job contract. Apart from the work entitlements another important concern is the quality of 
employment that is discussed under 'employment security'. The level of education attained is an important determinant of obtaining a better quality job; thus human capital formation leads to 'skill security'.

There are ample evidences that workers with insecure employment contracts are less likely to be provided with training. The People Security Survey (PSS) found that in India the illiterate and the people with minimal years of schools are mainly concentrated in casual and contractual work ILO (2004).

\subsection{Skill security}

It is increasingly argued that skill security is one of the important forms of securities as skill formation is the prerequisite to enhancing the quality of employment (NCEUS, 2009)(Note 9). It is developed from an individual's possession of basic education as well as technical education to obtaining a 'socially and economically valuable' occupation. Thus skill security is related to the formation of human capital. It is assumed that higher the level of education better is the level of income security. The important elements that are discussed with regard to skill security are:

(i) The general education of the workers

(ii) Received any vocational training

\subsubsection{The general education of the workers}

The skill attainment of the workforce is determined by their levels of general and technical education. The education level is divided into the following categories: not literate, literate up to primary, middle, secondary, higher secondary, diploma and certificate, graduate and above. Most of the workers in the informal sector enterprise have low levels of general education (see table 11).

Table 11. General education level of the nonagricultural informal sector workers

\begin{tabular}{lcccccc}
\hline Rural & \multicolumn{3}{c}{ West Bengal } & \multicolumn{3}{c}{ Kerala } \\
\cline { 2 - 7 } General education & Regular & Casual & $\begin{array}{l}\text { Self } \\
\text { employed }\end{array}$ & Regular & Casual & $\begin{array}{l}\text { Self } \\
\text { employed }\end{array}$ \\
\hline $\begin{array}{l}\text { Not literate } \\
\text { Literate \& below }\end{array}$ & 6.44 & 30.29 & 21.75 & 1.18 & 2.08 & 3.67 \\
primary & & & & & & \\
Primary \& Middle & 56.7 & 21.56 & 12.34 & 3.31 & 7.42 & 7.7 \\
Secondary \& higher & & 42.49 & 46.78 & 36.57 & 64.68 & 51.57 \\
secondary & 19.55 & 5.22 & 14.77 & 32.3 & 20.65 & 26.89 \\
*Diploma & 1.28 & 0 & 0.31 & 11.96 & 3.61 & 2.88 \\
Graduate \& above & 7.68 & 0.44 & 4.06 & 14.68 & 1.55 & 7.29 \\
\hline
\end{tabular}




\begin{tabular}{lcccccc}
\hline Urban & \multicolumn{3}{c}{ West Bengal } & \multicolumn{3}{c}{ Kerala } \\
\hline General education & Regular & Casual & $\begin{array}{l}\text { Self } \\
\text { employed }\end{array}$ & Regular & Casual & $\begin{array}{l}\text { Self } \\
\text { employed }\end{array}$ \\
\hline $\begin{array}{l}\text { Not literate } \\
\text { Literate \& below }\end{array}$ & 9.32 & 22.28 & 11 & 1.14 & 2.42 & 4.26 \\
primary & & & & & & \\
Primary \& Middle & 39.12 & 15.01 & 11.44 & 3.35 & 8.49 & 5.95 \\
Secondary \& higher & & 54.6 & 36.37 & 33.41 & 63.22 & 42.01 \\
secondary & 32.71 & 6.39 & 26.03 & 35.02 & 22.48 & 27.95 \\
*Diploma & 1.31 & 0 & 0.09 & 5.35 & 2.19 & 6.49 \\
Graduate \& above & 10.71 & 1.73 & 15.07 & 21.73 & 1.2 & 13.33 \\
\hline
\end{tabular}

Source: NSS $66^{\text {th }}$ Round (2009-10), Employment - Unemployment Survey, Author's calculation

Note: All the figures indicate percentages. *Diploma/ certificate courses, which were of graduation level or above, were classifiedunder the respective class of general education.

In Kerala the percentage of graduate among regular workers is relatively higher compared to West Bengal. The significant feature about Kerala is that the percentage of illiterates in all the activity status is low compared to West Bengal. The casual workers are the most vulnerable in terms of receiving education in the state of West Bengal as their share is the highest among the illiterates.

The low levels of general education of the informal enterprise workers result in lowering of their marketable skills. Thus skill insecurity is one of the major insecurities of this particular category of workers. The lack of skill is responsible for lowering of other forms of work related security.

In general the women have lower access to schooling and hence a lower level of skill security. In West Bengal though the level of female illiteracy is lower than the all India figure but still it is very high compared to Kerala. The share of females among illiterate workers is relatively high in West Bengal (see table 12). Apart from low female illiteracy the total number of male illiterates is low in Kerala. Majority of the workers in the informal enterprises have studied up to primary and middle standard. The respective percentages are 48 percent for males and 39 percent for the females in West Bengal and 58 percent for males and 38 percent for the females in Kerala. We also observe higher number of graduate informal workers in Kerala relatively higher than the national figure. The most important fact is that among the workers with qualifications up to higher secondary level, Kerala records higher proportion of females (29.6 percent) employed in the informal enterprises. 
Table 12. The level of education of the informal workers according to gender

\begin{tabular}{|c|c|c|c|c|c|c|}
\hline \multirow{2}{*}{$\begin{array}{l}\text { Rural } \\
\text { General Education }\end{array}$} & \multicolumn{2}{|c|}{ West Bengal } & \multicolumn{2}{|c|}{ Kerala } & \multicolumn{2}{|c|}{ India } \\
\hline & Male & Female & Male & Female & Male & Female \\
\hline Not literate & 19.53 & 35.78 & 1.85 & 7.16 & 22.24 & 44.68 \\
\hline Literate \& below primary & 13.14 & 15.21 & 6.43 & 9.84 & 10.91 & 10.15 \\
\hline Primary \& Middle & 48.26 & 38.72 & 57.81 & 38.26 & 41.51 & 31.01 \\
\hline \multicolumn{7}{|l|}{ Secondary \& higher } \\
\hline secondary & 14.5 & 7.53 & 24.30 & 29.63 & 19.78 & 10.92 \\
\hline Diploma & 0.39 & 0 & 4.12 & 6.3 & 1.07 & 0.71 \\
\hline Graduate \& above & 3.88 & 2.76 & 5.49 & 8.81 & 4.5 & 2.53 \\
\hline \multicolumn{7}{|l|}{ Urban } \\
\hline General Education & Male & Female & Male & Female & Male & Female \\
\hline Not literate & 11.78 & 13.95 & 1.95 & 7.79 & 13.14 & 30.88 \\
\hline Literate \& below primary & 10.31 & 17.69 & 6.66 & 5.9 & 7.56 & 9.11 \\
\hline Primary \& Middle & 38.62 & 40.45 & 49.99 & 43.12 & 34.92 & 30.43 \\
\hline Secondary \& higher & & & & & & \\
\hline secondary & 25.69 & 17.22 & 26.61 & 28.45 & 29.34 & 16.33 \\
\hline Diploma & 0.27 & 0 & 5.26 & 2.5 & 1.69 & 1.8 \\
\hline Graduate \& above & 13.33 & 10.69 & 9.53 & 12.23 & 13.35 & 11.45 \\
\hline
\end{tabular}

Source: NSS $66^{\text {th }}$ Round (2009-10), Employment - Unemployment Survey, Author's calculation

Note: All the figures indicate percentage

Since a significant proportion of the informal workers in West Bengal is not literate compared to Kerala it raises the level of vulnerability for these workers. With better skill security in terms of higher level of general education the informal workers in Kerala can cope with the insecurities in a better way. Apart from the functional literacy, the availability of vocational training also gives an indication of skill security. The main purpose of vocational training is to prepare the young population to develop marketable skill thus enhancing the prospect of employment. The vocational training also helps them generate specific skill that can create opportunities for self-employment.

\subsubsection{Skill acquisition through vocational training}

The analysis of the data on skill acquisition shows that the attainment of skill is low in general (see table 13). In rural West Bengal 25 percent of male has training compared to 28 percent of female workers; whereas in urban areas relatively greater number of females have undergone training. In Kerala though in the rural areas higher numbers of female workers have undertaken training but in the urban areas the findings are reverse. The level of vocational training in the urban areas is low because the general level of education being higher the workers get involved in relatively other forms of skill training. 
Table 13. Percentage of nonagricultural informal workers with attainment of training

\begin{tabular}{lcccccc}
\hline & \multicolumn{2}{c}{ West Bengal } & \multicolumn{2}{c}{ Kerala } & \multicolumn{2}{c}{ India } \\
\cline { 2 - 7 } Sector & Male & Female & Male & Female & Male & Female \\
\hline Rural & 24.55 & 27.5 & 26.38 & 34.23 & 16.61 & 16.7 \\
Urban & 19.78 & 29.33 & 29.19 & 18.98 & 16.68 & 20.66 \\
\hline
\end{tabular}

Source: NSS 66 ${ }^{\text {th }}$ Round (2009-10), Employment - Unemployment Survey, Author's calculation

Note: All the figures indicate percentages

The workers in the informal enterprises show a greater dependence on informal sources of training (see table 14). The dependence on the informal sources is high in West Bengal relative to Kerala as the state of Kerala records fairly greater number of formal institutions delivering training courses. But a significant feature about the data is that majority of the workers both in West Bengal and Kerala have not received any training.

Table 14. The skill level of the non-agricultural informal sector workers

\begin{tabular}{lcccccc}
\hline $\begin{array}{l}\text { Sources of } \\
\text { vocational } \\
\text { training }\end{array}$ & \multicolumn{3}{c}{ West Bengal } \\
\cline { 2 - 7 } Rural & Regular & Casual & $\begin{array}{l}\text { Self } \\
\text { employed }\end{array}$ & Regular & Casual & $\begin{array}{l}\text { Self } \\
\text { employed }\end{array}$ \\
\cline { 2 - 7 } Kormal & 0.35 & 0.42 & 1.42 & 18.11 & 6.6 & 12.1 \\
Informal & 33.23 & 27.8 & 21.76 & 11.28 & 15.63 & 20.34 \\
No training & 66.42 & 71.78 & 76.83 & 70.61 & 77.76 & 67.56 \\
\hline Urban & & & & & & \\
\hline Formal & 2.9 & 0 & 2.5 & 10.86 & 7.22 & 13.76 \\
Informal & 21.64 & 22.7 & 17.41 & 15.01 & 15.66 & 17.93 \\
No training & 75.46 & 77.3 & 80.09 & 73.48 & 77.77 & 68.31 \\
\hline
\end{tabular}

Source: NSS 66 ${ }^{\text {th }}$ Round (2009-10), Employment - Unemployment Survey, Author's calculation

Note: All the figures indicate percentages

The formal sources of training include ITI, Polytechnic, schools offering vocational courses, Hospital and Medical training institutes and other recognized training institutes. The informal sources include hereditary, self learning and on job training methods. Majority are dependent on the informal sources which include hereditary method that is acquiring skills from the family members at home. Self-learning is a well-known method of skill acquisition in the informal or unregistered sectors where the new workers learn the skill by looking at other workers performing the particular skill. A large number of workers employed in the urban informal enterprises reported that they had no training at all.

A strong link exists between the access to general education and access to training facilities and also the type of training. In general the higher the level of general education there are more opportunities for skill training both institutional and on job training. We observe the general pattern that the level of skill acquisition through informal training is higher in the lower levels of education (see table 15). 
Table 15. Percentage of workers in the age-group of 15-59 years with vocational training by education

\begin{tabular}{|c|c|c|c|c|c|c|}
\hline \multirow{2}{*}{$\begin{array}{l}\text { Rural } \\
\text { General Education }\end{array}$} & \multicolumn{2}{|c|}{ West Bengal } & \multicolumn{2}{|c|}{ Kerala } & \multicolumn{2}{|c|}{ India } \\
\hline & Formal & Informal & Formal & Informal & Formal & Informal \\
\hline Not literate & 0 & 19.6 & 0 & 2.65 & 0.3 & 17.67 \\
\hline Literate \& below primary & 2.25 & 12.99 & 0 & 3.34 & 1.32 & 9.38 \\
\hline Primary \& Middle & 35.47 & 56.01 & 30.47 & 68.24 & 26.17 & 49.28 \\
\hline \multicolumn{7}{|l|}{ Secondary \& higher } \\
\hline secondary & 18.11 & 9.74 & 24.77 & 29.41 & 28.67 & 20.73 \\
\hline Diploma & 2.3 & 0.67 & 30.68 & 0.39 & 24.55 & 0.46 \\
\hline Graduate \& above & 41.87 & 0.99 & 14.08 & 0.97 & 18.99 & 2.48 \\
\hline \multicolumn{7}{|l|}{ Urban } \\
\hline & \multicolumn{2}{|c|}{ West Bengal } & \multicolumn{2}{|c|}{ Kerala } & \multicolumn{2}{|c|}{ India } \\
\hline General Education & Formal & Informal & Formal & Informal & Formal & Informal \\
\hline Not literate & 0 & 11.41 & 1.24 & 1.4 & 0.43 & 13.19 \\
\hline Literate \& below primary & 0 & 14.37 & 0 & 8.24 & 0.9 & 9.61 \\
\hline Primary \& Middle & 24.15 & 52.23 & 35.63 & 52.34 & 12.89 & 45.95 \\
\hline \multicolumn{7}{|l|}{ Secondary \& higher } \\
\hline secondary & 18.53 & 19.47 & 22.73 & 28.65 & 27.57 & 25.42 \\
\hline Diploma & 0.42 & 0.13 & 25.7 & 4.92 & 20.65 & 0.71 \\
\hline Graduate \& above & 56.9 & 2.39 & 14.7 & 4.44 & 37.57 & 5.12 \\
\hline
\end{tabular}

Source: NSS 66 ${ }^{\text {th }}$ Round (2009-10), Employment - Unemployment Survey, Author's calculation Note: All the figures indicate percentages

The proportion of formally trained workers is high among the graduates in West Bengal; 42 percent in rural and 57 percent in urban. In Kerala the proportion of formally trained workers is found to be high among the diploma holders; the skill formation through formal training methods tends to rise with primary and middle level of education. The performance of formal training is poor in the lower levels of education because the minimum requirement to get admission to the vocational training course such as ITIs is secondary or higher secondary qualification.

The relationship between skill formation and education is further studied through binary logit regression. The access to training is taken as an indicator of skill security among the workers using a logistic regression model.

The dependent variable is vocational training (Training undertaken, formal and informal/No training). Here we study the impact of education, social group, gender and sector (Rural/Urban) on the level of vocational training (formal and informal) attained. The age group of the workers studied is 15 to 59 years.

The regression results are reported in the tables 16.1, 16.2 and 16.3. 
Table 16.1. Logit regression results for West Bengal

\begin{tabular}{|c|c|c|}
\hline Explanatory variables & Coefficient & Odds ratio \\
\hline Constant & $-2.655 *$ & \\
\hline \multicolumn{3}{|l|}{ Sector } \\
\hline \multicolumn{3}{|l|}{ Rural ® } \\
\hline Urban & $-0.239 * * *$ & 0.787 \\
\hline \multicolumn{3}{|l|}{ Sex } \\
\hline \multicolumn{3}{|l|}{ Female ${ }$} \\
\hline Male & $-0.291 * * *$ & 0.747 \\
\hline \multicolumn{3}{|l|}{ Education } \\
\hline \multicolumn{3}{|l|}{ Illiterate \& below primary ${ }^{\circledR}$} \\
\hline Primary \& Middle & $0.323 * *$ & 1.381 \\
\hline Secondary and above & $-0.353 * *$ & 0.702 \\
\hline \multicolumn{3}{|l|}{ Social Group } \\
\hline \multicolumn{3}{|l|}{$\mathrm{ST} \circledast$} \\
\hline SC & $1.165^{*}$ & 3.205 \\
\hline OBC & $1.628 *$ & 5.095 \\
\hline Others & $1.971 *$ & 7.179 \\
\hline \multicolumn{3}{|l|}{ Author's calculation } \\
\hline \multicolumn{3}{|l|}{ *significant at $\mathrm{p}<0.01$} \\
\hline \multicolumn{3}{|l|}{ ficant at $\mathrm{p}<0.05$} \\
\hline ificant at $\mathrm{p}<0.1$ & & \\
\hline ence category & & \\
\hline
\end{tabular}

Table 16.2. Logit regression results for Kerala

\begin{tabular}{lcc}
\hline Explanatory variables & Coefficient & Odds ratio \\
\hline $\begin{array}{l}\text { Constant } \\
\text { Sector }\end{array}$ & $-2.884^{*}$ & \\
Rural ${ }^{\circledR}$ & & \\
Urban & -0.072 & 0.931 \\
Sex & & \\
Female ${ }^{\circledR}$ & & \\
Male & -0.120 & 0.887 \\
Education & & \\
Illiterate \& below primary ${ }^{\circledR}$ & & \\
Primary \& Middle & $0.58^{* *}$ & 1.787 \\
Secondary and above & $0.960^{*}$ & 2.612 \\
Social Group & & \\
ST ${ }^{\circledR}$ & & 3.221 \\
SC & $1.170^{* * *}$ & 4.09 \\
OBC & $1.409^{* * *}$ & 3.336 \\
Others & $1.205^{* * *}$ & \\
\hline
\end{tabular}


Table 16.3. Logit regression results for India

\begin{tabular}{lcc}
\hline Variables & Coefficient & Odds ratio \\
\hline Constant & $-2.452^{*}$ & \\
Sector & & -- \\
Rural $₫$ & -- & 0.965 \\
Urban & -0.035 & \\
Sex & & -- \\
Female ${ }^{\circledR}$ & -- & 0.792 \\
Male & $-0.233^{*}$ & \\
Education & & -- \\
Illiterate \& below primary ${ }^{\circledR}$ & -- & 1.678 \\
Primary \& Middle & $0.518^{*}$ & 1.560 \\
Secondary and above & $0.445^{*}$ & \\
Social Group & & -- \\
ST ${ }^{\circledR}$ & -- & 1.657 \\
SC & $0.505^{*}$ & 2.162 \\
OBC & $0.771^{*}$ & 2.198 \\
Others & $0.787^{*}$ & \\
\hline
\end{tabular}

Source: Author's calculation

Notes: *significant at $\mathrm{p}<0.01$

**significant at $\mathrm{p}<0.05$

$* * *$ Significant at $\mathrm{p}<0.1$

R: Reference category

In the above analysis we try to study the likelihood of getting trained becomes high with higher levels of education, higher degree of urbanization, presence of higher castes. Thus we account for certain independent factors which are likely to affect the vocational training by sex, residence, social group and education. The regression analysis (tables 16.1, 16.2 and 16.3) describes the influence of the independent factors on the level of training achieved. The reference variables are rural areas as place of residence, female among gender, ST among social group and illiterate and below primary among education.

In West Bengal we observe that higher proportion of workers in the rural nonagricultural informal enterprises has received training compared to the urban informal enterprises. The relationship between training acquired and urban residence is negative at 10 percent level of significance. In the rural areas of Kerala we observe higher proportion of workers have received training compared to the urban areas; but the result is insignificant. There is no significant difference between rural and urban with attainment of training. Thus urban residence does not necessarily increase the likelihood of obtaining training.

In West Bengal male has lower chance of getting trained compared to the female counterparts at 10 percent level of significance. This finding is similar to the national pattern which also shows relatively lower likelihood for the males to obtain training. In Kerala the male-female divergence with respect to attainment of training is insignificant. Since the number of literates 
are high both in the rural and urban areas of Kerala it increases the likelihood of getting enrolled in vocational training institutes.

With regard to skill formation there are differences among the social groups. In West Bengal the social group has significant influence on the chance of getting trained. The SCs, OBCs and Others have shown higher chance of getting trained compared to ST. This finding is similar to the national pattern. In Kerala, the SCs, OBCs and others have higher likelihood of getting trained at 10 percent level of significance.

The likelihood of an educated person being trained rises significantly with higher level of education in Kerala. Whereas in both rural and urban areas of West Bengal the chance of getting trained falls significantly when one moves from primary and middle towards secondary and above level of education. This results in the negative relationship between training obtained versus and higher level of education. On the contrary, we find that in Kerala the likelihood of getting trained rises significantly at higher levels of education. This result supports the observation obtained from all India data where we obtain a positive relationship between training obtained and higher level of education.

It is assumed that greater the level of education and training lower is the level of other forms of insecurity. The level of skill security being low among the workers in the informal enterprises results in low employment security in terms of no written form of job contract.

The casual workers form the more vulnerable section of workers by the nature of job contract and poor level of education. Majority of this particular category of workers receive wages according to their daily performances and hence are not entitled to paid leave benefit. Thus majority of the informal enterprise workers have poor level of skill which limit their opportunities to move to better paid jobs. Another important aspect of security is 'job security' which is concerned with perceived satisfaction with the present level of employment.

\subsection{Job security}

The level of education enhances the level of job security by creating opportunities to develop competencies to seek job according to one's choice. Job security is the measure of extent of control over the content of one's job; the opportunities that one has for building one's career. This form of security is associated with employment security and skill security [ILO, 2004; p.221]. It is related to employment security as it captures the subjective perception of an individual's work that is the degree of satisfaction with the current job.

An important indicator to measure job security is the perceived difficulty of obtaining a job commensurate with the degree of satisfaction. In this context we study the workers who looked for alternative work when they are already employed in the informal enterprises. The major reason for seeking alternative work is that the present work is not remunerative. The self-employed, regular and casual workers reported that the return from the current employment was not rewarding. In fact, a majority of the workers irrespective of the activity status have reported their dissatisfaction for the current level of earning (see figures 3 \& 4). In urban West Bengal the percentage of regular workers perceiving the current employment 


\section{Mll Macrothink}

Research in Applied Economics

ISSN 1948-5433

2014, Vol. 6, No. 3

as non-remunerative is the highest (78 percent). Whereas in rural West Bengal the level of dissatisfaction of the regular workers compared to the casual workers is low. In Kerala the regular workers in majority reported their current employment as non-rewarding and hence they sought alternative work. Thus the workers across all activity status have reported that the urge to earn higher income has led them to search for a new job.

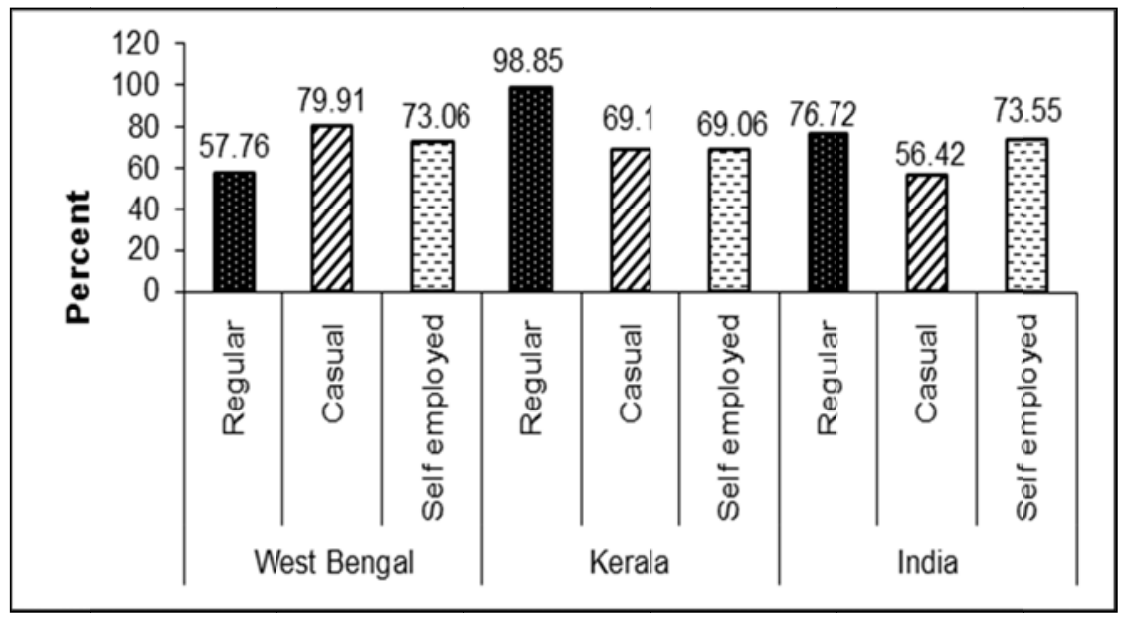

Source: NSS $66^{\text {th }}$ Round (2009-10), Employment - Unemployment Survey; computed

Figure 3. Workers reporting present work as non-remunerative inrural non-agricultural enterprises

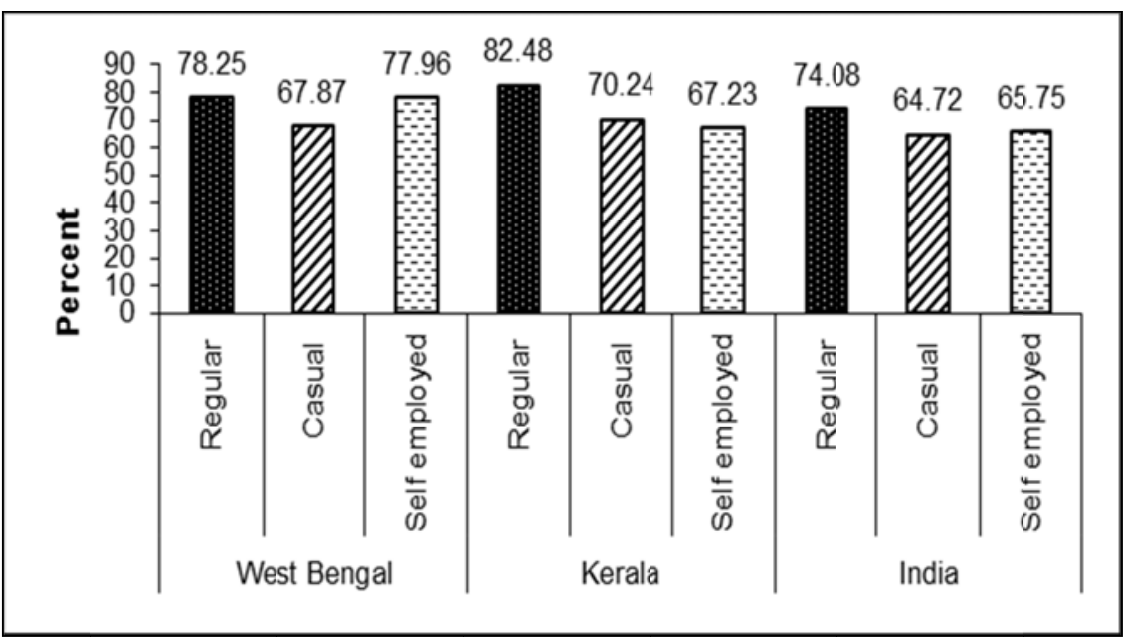

Source: NSS $66^{\text {th }}$ Round (2009-10), Employment - Unemployment Survey; computed

Figure 4.Workers reporting present work as non-remunerative inurban non-agricultural enterprises

\subsubsection{Self-employment and job security}

The self-employed workers have a short term relationship with their customers and do not enjoy rights and benefits which is associated with any employment relationship (ILO, 2004; p.230-234).Hence they do not enjoy any employment security. But the notion of job security is applied for the self-employed workers. A subjective perception of work satisfaction is 


\section{Ml Macrothink}

attached to their activity levels even if they determine their own employment conditions. The remuneration level is an important determinant of the degree of satisfaction. Thus NSS has asked the question that whether they regard the remuneration generated from their current employment as rewarding or not. The degree of satisfaction also varies across various categories of self-employed workers (see figures 5 \& 6). In West Bengal higher number of self-employed workers reported that the income generated from self-employment is non-remunerative. It is obtained that in the rural nonagricultural self-employment, 67 percent of own account workers considered the current earning from the self-employment as non-remunerative while the corresponding percentages for the employer category is 26 percent and for the unpaid family worker is 74 percent. The corresponding percentages in the urban areas are 68 percent for the own account workers, 55 percent for the employers and 61 percent for the unpaid family workers. On the contrary greater percentage of self-employed workers in nonagricultural informal enterprise of Kerala reported that their employment generate sufficiently gainful income.

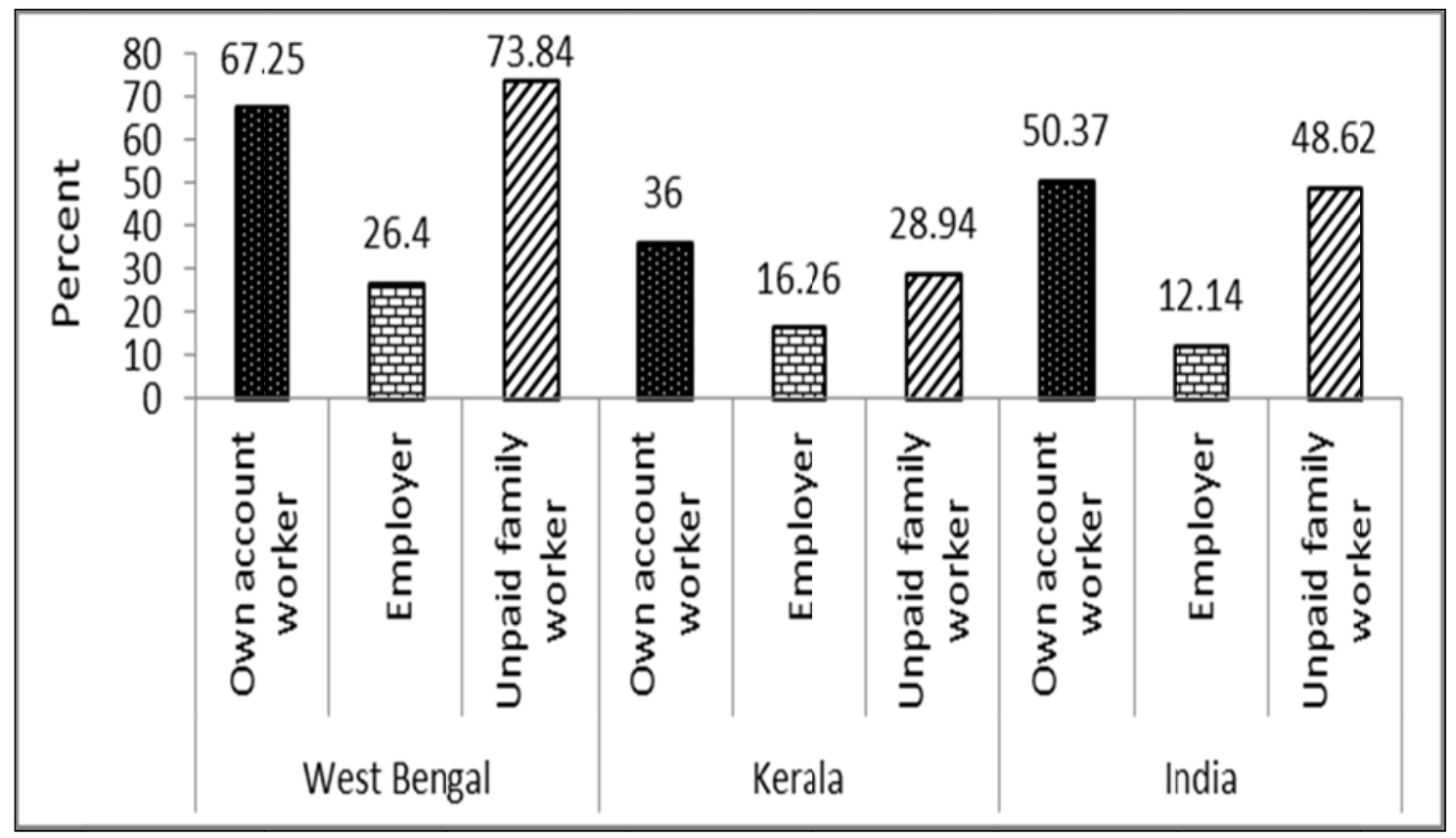

Source: NSS $66^{\text {th }}$ Round (2009-10), Employment - Unemployment Survey, computed.

Figure 5. Percentage of workers reporting self-employment as non-remunerative inrural non-agricultural informal enterprises 


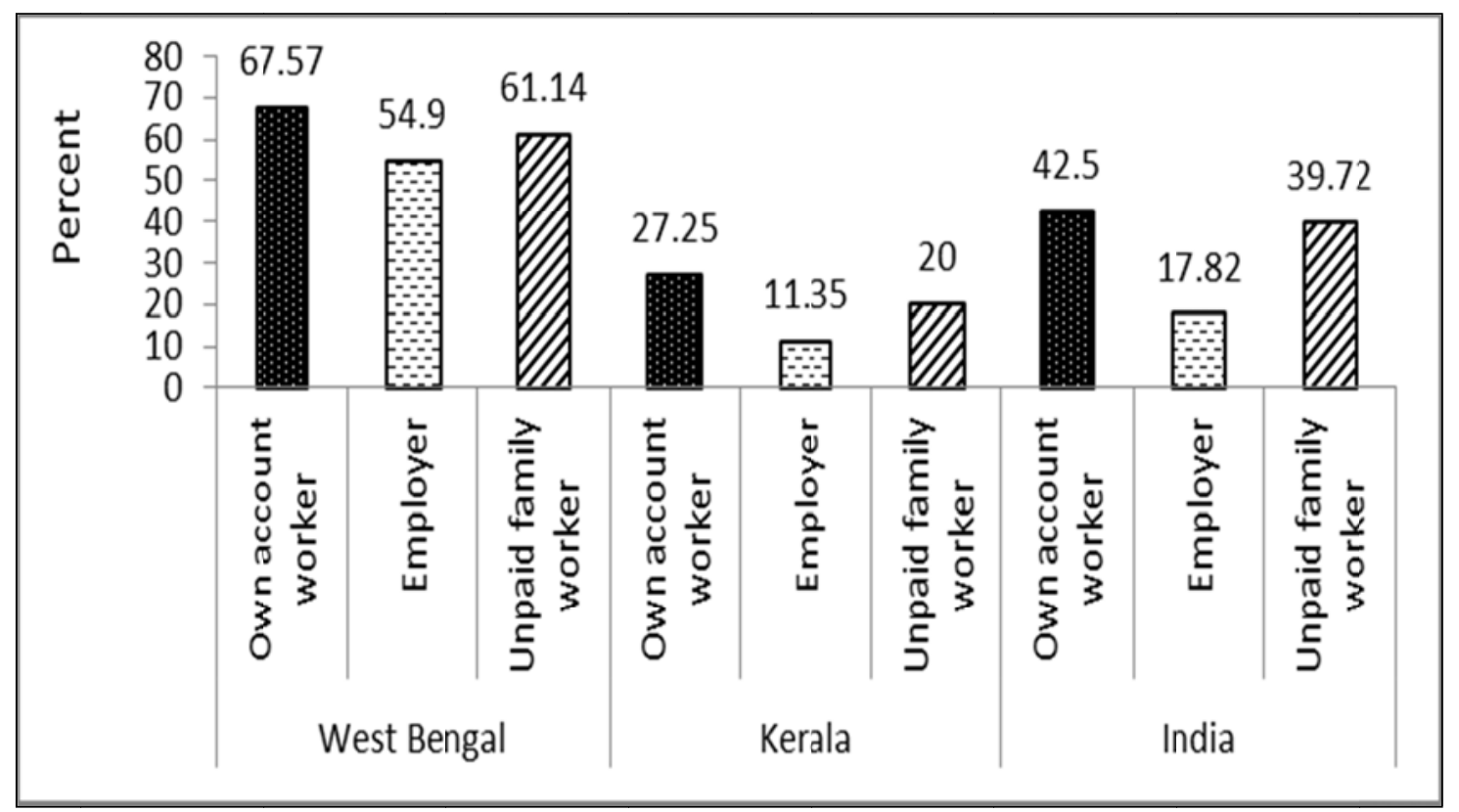

Source: NSS 66 ${ }^{\text {th }}$ Round (2009-10), Employment - Unemployment Survey, computed.

Figure 6. Percentage of workers reporting self-employment as non- remunerative inurban non-agricultural informal enterprises

The responses in support of the remunerative self-employment indicate a higher degree of satisfaction with regard to current earning status. The level of satisfaction that is generated from the current earning is not positively related to the level of income earned, but it constitutes a major source of income security (ILO, 2004).

\subsection{Representation security}

The representation security is an important form of security as it is related to the recognition aspect of the workers. Voice representation is an instrumental freedom(Note 10) of the individuals to negotiate over the wages, benefits and working conditions. The idea of representation combines both individual and collective representation (ILO, 2004; p.247). The individual representation is about asserting rights protected by laws and collective representation implies formation of a group that work according to the interests of the individuals. The organization consisting of a collection of individuals directed to protect the vulnerable workers is the 'Trade Union'.

The two roles of the trade unions identified by Jose (2004) include (i) an economic role related to ensuring equitable distribution of income primarily through the structure of wage bargaining and participating in the process of determining the result wages at the industry level (ii) a representative role at involves providing identity and voice to the workers. Thus the existence of trade unions at workplaces lead to improvement in various work related securities. It is true that the freedom of association is mainly concentrated in the organized sectors of the economy whereas it is really difficult to organize the informal workers as they form a heterogeneous category. The lack of awareness among the workers is an underlying factor behind low unionization of the informal workers. According to ILO (2004), it is 
difficult to organize the workers engaged in the informal labour relationships because they are either not aware of the existence of unions or particularly unaware that the unions can represent their interests.

As the unorganized or informal enterprise workers have a weak bargaining position by the nature of their employment contract we look into the aspect of representation security through their membership in unions(Note 11) (See tables 17 and 18). It shows that majority of the workers across all activity status do not have unions in their economic activities. The representation security of the female workers in the rural and urban informal enterprises of West Bengal is negligible.

In Kerala the representation security of the informal workers is comparatively higher than that of West Bengal. In case of casual workers relatively lower number of them in the informal enterprises of Kerala has reported about nonexistence of union in their activities. In the informal enterprises of West Bengal the casual workers have no presence of union in their workplaces. The presence of trade unions among the casual workers of Kerala indicates their collective organizational power. It has resulted in the generation of a large number of welfare funds for the casual workers in the state of Kerala. But in West Bengal the strength of unionization among the casual workers is very poor.

Table 17. Percentage of various categories of workers in rural non-agricultural informal enterprises with non-existence of union

\begin{tabular}{lcccccc}
\hline \multirow{2}{*}{ Status of Employment } & \multicolumn{2}{c}{ West Bengal } & \multicolumn{2}{c}{ Kerala } & \multicolumn{2}{c}{ India } \\
\cline { 2 - 7 } & Male & Female & Male & Female & Male & Female \\
\hline Own account worker & 77.20 & 95.01 & 33.63 & 48.83 & 81.45 & 90.82 \\
Employer & 76.68 & - & 16.98 & 0 & 53.44 & 84.55 \\
Unpaid family worker & 87.03 & 80.73 & 55.13 & 41.10 & 84.00 & 83.43 \\
Regular wage employee & 94.82 & 99.64 & 61.15 & 74.82 & 83.47 & 75.44 \\
Casual labour & 89.76 & 90.67 & 42.60 & 42.10 & 86.72 & 88.67 \\
\hline
\end{tabular}

Source: NSS $66^{\text {th }}$ Round (2009-10), Employment - Unemployment Survey, Author's calculation Note: All the figures indicate percentage.

Table 18. Percentage of various categories of workers in urban non-agricultural informal enterprises with non-existence of union

\begin{tabular}{lcccccc}
\hline \multirow{2}{*}{ Status of Employment } & \multicolumn{2}{c}{ West Bengal } & \multicolumn{2}{c}{ Kerala } & \multicolumn{2}{c}{ India } \\
\cline { 2 - 7 } & Male & Female & Male & Female & Male & Female \\
\hline Own account worker & 69.83 & 91.51 & 38.19 & 53.13 & 71.27 & 87.73 \\
Employer & 72.83 & - & 30.45 & 45.58 & 56.82 & 66.31 \\
Unpaid family worker & 74.74 & $89.25-$ & 34.94 & 55.67 & 73.21 & 79.01 \\
Regular wage employee & 85.18 & 89.39 & 69.23 & 71.44 & 87.20 & 84.96 \\
Casual labour & 77.77 & 100 & 54.96 & 78.95 & 82.07 & 87.47 \\
\hline
\end{tabular}

Source: NSS 66 ${ }^{\text {th }}$ Round (2009-10), Employment - Unemployment Survey, Author's calculation Note: All the figures indicate percentages 
The self-employed workers in Kerala have relatively higher trade union activities; it is completely absent in rural West Bengal. This represents the strong representation security of the self employed workers in the informal enterprises of Kerala.

The female representation security among the own account workers in the informal enterprises of Kerala is higher than the male counterparts. The representation security does not exist among the female own account workers of West Bengal.

The existence of low trade union membership among the regular workers proves that their collective strength is non-existent. There is also an issue of trust on the union leaders that they represent the interests of the working class. The loss of confidence on the union leaders also results in alienation of the workers from the union leaders. According to ILO (2004), the period of globalization has witnessed a lowering of centralized bargaining and there is an emergence of independent local unions. The major difficulty with the independent local unions and unaffiliated unions is their financial vulnerability.

\subsubsection{Education status of the union members}

The education of the union members shows that many among the illiterates have joined the unions, primarily because of presence of information of the existence of the unions. In rural West Bengal the female representation is $44 \%$ in primary and middle standard. In the urban areas the female representation is $99.6 \%$ in below primary standard. In Kerala large numbers of female union members are illiterate compared to West Bengal. The male representation is comparatively high from the higher levels of education (see table 19).

Table 19. The education status of the members of unions according to gender

\begin{tabular}{|c|c|c|c|c|c|c|}
\hline \multicolumn{7}{|l|}{ Rural } \\
\hline \multirow[b]{2}{*}{ General Education } & \multicolumn{2}{|c|}{ West Bengal } & \multicolumn{2}{|c|}{ Kerala } & \multicolumn{2}{|c|}{ India } \\
\hline & Male & Female & Male & Female & Male & Female \\
\hline Not literate & 82.02 & 48.75 & 27.90 & 78.74 & 62.78 & 53.33 \\
\hline Literate $\&$ below primary & 71.16 & 100 & 68.71 & 36.55 & 65.11 & 46.39 \\
\hline Primary \& Middle & 82.80 & 44.44 & 67.48 & 67.76 & 63.01 & 48.33 \\
\hline Secondary \& higher secondary & 79.34 & 0 & 65.05 & 40.33 & 64.98 & 57.79 \\
\hline Diploma & 100 & - & 56.28 & 38.67 & 53.88 & 49.23 \\
\hline Graduate \& above & 80.11 & 100 & 69.49 & 100 & 77.47 & 89.16 \\
\hline \multicolumn{7}{|l|}{ Urban } \\
\hline & \multicolumn{2}{|c|}{ West Bengal } & \multicolumn{2}{|c|}{ Kerala } & \multicolumn{2}{|c|}{ India } \\
\hline General Education & Male & Female & Male & Female & Male & Female \\
\hline Not literate & 95.14 & 65.01 & 73.19 & 61.70 & 68.10 & 30.89 \\
\hline Literate $\&$ below primary & 89.50 & 99.67 & 63.90 & 56.77 & 63.29 & 43.11 \\
\hline Primary \& Middle & 84.63 & 6.32 & 61.59 & 46.85 & 65.66 & 33.12 \\
\hline Secondary \& higher secondary & 81.81 & 100 & 66.39 & 36.44 & 75.17 & 43.35 \\
\hline Diploma & 78.67 & - & 71.48 & 100 & 69.12 & 64.18 \\
\hline Graduate \& above & 92.87 & 66.66 & 75.50 & 44.39 & 87.88 & 82.36 \\
\hline
\end{tabular}

Source: NSS 66 ${ }^{\text {th }}$ Round (2009-10), Employment - Unemployment Survey, Author's calculation

Note: All the figures indicate percentages 
The representation security of the workers forms an important source of economic security of the workers. Among the seven forms of security described primal importance is given to representation security and basic income security. The basic income security is important as it enlarges the opportunity set of individuals to make rational decisions and representation security allows them to get rid of from the vulnerabilities at the workplace.

\section{Conclusion}

The essay is an attempt to describe the various forms of insecurities faced by the workers in the nonagricultural informal enterprises of the states of West Bengal and Kerala. The analysis finds out that the workers in the informal enterprises irrespective of which state they belong to do not enjoy any employment security (written job contract) and work security (paid leave or social security benefits). The reported status of 'employed' does not necessarily imply that the workers earn a reasonable level of earnings or have decent conditions of work. In few cases the observations obtained in Kerala differ from that of West Bengal particularly with respect to skill security. A large number of casual workers in West Bengal are illiterates which have also reduced their access towards obtaining vocational training. The lack of training increases the risk of getting insecure jobs. In Kerala the number of illiterates across all activity status being low the level of general education is high. The casual and self employed workers in both rural and urban areas of Kerala have studied upto primary and middle standard. The significant proportion of literates in Kerala results in higher achievement of skill acquisition. The male-female difference in terms of skill acquisition in Kerala is not significant which implies that the female informal workers receive training and hence are better in terms of human capital formation.

Another important aspect of vulnerability of the workers is the social groups to which they belong. In the informal enterprises of both the states, the workers belonging to ST community are relatively more vulnerable due to the lack of formation of marketable skills through skill acquisition.

With respect to income security the regular and the casual workers in Kerala are secure enough as their average daily earning is higher compared to the national average daily earnings of the respective workers. Thus better income security earns them a proper livelihood than the same section of workers employed in the informal enterprises of West Bengal. These workers not only receive wage/salary below the national level but the range of minimum wage lies much below the centrally fixed level. The informal workers in West Bengal in addition have low collective strength which further accentuates the work related insecurities. Thus the growth of the informal sector enterprises implies increasing income insecurity and vulnerability of the workers. This requires comprehensive social protection for the workers in the informal enterprises to include economic security and social security measures that combine to form the idea of basic security. The need to design acceptable conditions of work based on moral philosophy and human rights is also suggested by the National Commission of Enterprises on Unorganized sector Workers (NCEUS) following the principle of International Labour Organization (ILO). 


\section{Acknowledgement}

The paper is produced out of the M.Phil dissertation titled, 'Labour Market Dynamics and Social Security: A Study of West Bengal', submitted to Institute of Development Studies Kolkata, University of Calcutta, India in 2012. I thank Professor Achin Chakraborty and Professor Byasdeb Dasgupta for their valuable and helpful comments. Any remaining errors are mine.

\section{References}

Dreze, J., \& Sen, A.K. (2004). Public Action for Social Security: Foundations and Strategy. In E. Ahmad, J. Dreze, J. Hills and A. K. Sen (Eds.) Social Security in Developing Countries. New Delhi: Oxford University Press.

Dreze,J., \& Sen, A.K. (1989).Hunger and Public Action. New Delhi: Oxford University Press.

Eyraud, F., \&Saget, C. (2005). Fundamentals of Minimum wage fixing. Geneva: International Labour Organization. Retrieved from http://www.ilo.org/wcmsp5/groups/public/---ed_dialogue/---actrav/documents/meetingd ocument/wcms_208814.pdf

International Labour Organization (2002). Decent Work and the Informal Economy. Retrieved from http://www.ilo.org/public/english/standards/relm/ilc/ilc90/pdf/rep-vi.pdf

International Labour Organization (2004). Economic Security for a Better World. Retrieved from

http://www.social-protection.org/gimi/gess/RessourcePDF.action;jsessionid=e666a8b86 c230b4b9938e219905ce25bcc3df494bf37ace973cbbaeab5fbf671.e3aTbhuLbNmSe34M chaRah8TbNn0?ressource.ressourceId=8670

Jhabvala, R. (1998). Social Security for Unorganized Sector.Economic and Political Weekly, 33(22), L-7-L11.

Jose, A. V. (2004). Dignity at work. Economic and Political Weekly, 39(40), 4447-4454.

Kannan, K.P., \& Francis, S. K. (2001). State Assisted Social Security for Poverty Alleviation and Human Development: Kerala's Records and its Lessons. In M. Dev et. al. (Eds) Social and Economic Security in India, New Delhi: Institute for Human Development.

National Commission for Enterprises in the Unorganized Sector (2007). Conditions of Work and Promotion of Livelihoods in the Unorganized Sector.Government of India. Retrieved from http://www.prsindia.org/uploads/media/Unorganised\%20Sector/bill150_20071123150_ Condition_of_workers_sep_2007.pdf

National Commission for Enterprises in the Unorganized Sector (2009). The Challenge of Employment in India- An Informal Economy Perspective.Government of India. 
Retrieved from http://nceuis.nic.in/The_Challenge_of_Employment_in_India.pdf

National Commission for Enterprises in the Unorganized Sector (2009). Skill Formation and Employment Assurance in the Unorganized Sector. Government of India. Retrieved from

http://nceuis.nic.in/Skill_Formation_and_Employment_Assurance_in_the_Unorganised _Sector.pdf

National Sample Survey Organisation (2012).Informal Sector and Conditions of employment in India. Government of India. Retrieved from http://www.indiaenvironmentportal.org.in/files/file/informal\%20sector\%20and\%20empl oyment\%20in\%20india.pdf

Sen, A.K. (1975). Employment Technology and Development. New Delhi: Oxford University Press.

Sen. S., \& Dasgupta, B. (2009). Unfreedom and Waged Work-Labour in India's Manufacturing Industry. New Delhi: Sage Publications. http://dx.doi.org/10.4135/9788132102526

Standing, G. (1999). Global Labour Flexibility: Seeking Distributive Justice. London: Macmillan Press.

Standing, G. (2008). Reviving Egalitarianism in the Global Transformation: Building Occupational security. Indian Journal of Human Development, 2(1), 39-62.

Unni, J., \& Rani, U. (2002a). Social Protection for Informal Workers: Insecurities, Instruments and Institutional Mechanisms. Geneva: International Labour Office. Retrieved from http://www.oit.org/public/english/protection/ses/download/docs/informal_workers.pdf

Unni, J., \& Rani, U. (2002b). Insecurities of Informal Workers in Gujarat, India. Geneva: International Labour Office. Retrieved from http://natlex.ilo.ch/public/english/protection/ses/download/docs/india_informal.pdf

\section{Notes}

Note 1. NSS defines the usual principal activity status relates to the activity status of a person during the reference period of 365 days preceding the date of survey.The activity status is the economic and non-economic situation in which the person is found to be engaged during the reference period.

Note 2. For details see the report on 'The Challenge of Employment in India- An Informal Economy Perspective' by National Commission for Enterprises in the Unorganized Sector (NCEUS), 2009, p. 12.

Note 3. For further details see the Report NCEUS (2007): Report on Conditions of Work and Promotion of livelihoods in the Unorganized sector, page-42 
Note 4. NSS Report No: 539, $66^{\text {th }}$ Round, 2009-10

Note 5. For further details see the Report on 'Decent Work and the Informal Economy', ILO, 2002.

Note 6. For further details see the chapter-7 on 'Work Security' in the report titled, Economic Security for a Better World (ILO, 2004).

Note 7. According to the NSS report on 'Informal Sector and Conditions of Employment (2009-10), the social security benefits include Provident Fund (PF), gratuity, health care and maternity benefits. The term PF include General Provident fund, contributory PF, Public PF, EPF etc. Those social security schemes are included in which both the employer and employee have contributed. In case if the PF account is operated by the individual and not contributed by the employer, it is not considered as a social security benefit. Thus coverage under any of the social security schemes implies that the employer has either arranged or contributed to implementing the social security benefit of the worker.

Note 8. The paid leave benefits are those which are given by the employer during the period of illness, maternity or such related things.

Note 9. For further details see the report on 'Skill Formation and Employment Assurance in the Unorganized Sector' (NCEUS, 2009)

Note 10. Sen's idea of instrumental freedom is concerned with the way different kinds of rights, opportunities and entitlements contribute to the expansion of human freedom and thus resulting in development. For greater details see Development as Freedom by A.K Sen (2003).

Note 11. The union or association refers to a body whose membership is open to those sections of people who are engaged in a specific activity. This category also includes the association of owners and self -employed persons. 
Appendix Table 1: Range of minimum wages for unskilled workers in different states

\begin{tabular}{|c|c|}
\hline State/Union Territory & Range of Minimum Wages per day (in rupees) \\
\hline Central & $78.00-186.00$ \\
\hline West Bengal & $57.01-126.42$ \\
\hline Andhra Pradesh & $58.25-163.00$ \\
\hline Arunachal Pradesh & 55 \\
\hline Assam & $54.80-79.60$ \\
\hline Bihar & $75.00-89.00$ \\
\hline Chhattisgarh & $69.00-103.28$ \\
\hline Goa & $90.00-110.00$ \\
\hline Gujarat & $55.00-115.80$ \\
\hline Haryana & 138 \\
\hline Himachal Pradesh & 100 \\
\hline Jammu \& Kashmir & 66 \\
\hline Jharkhand & $86.40-90.00$ \\
\hline Karnataka & $73.96-133.10$ \\
\hline Kerala & $72.00-328.80$ \\
\hline Madhya Pradesh & $88.20-133.65$ \\
\hline Maharashtra & $46.13-201.30$ \\
\hline Manipur & 72.4 \\
\hline Meghalaya & 70 \\
\hline Mizoram & 103 \\
\hline Nagaland & $66.00-70.00$ \\
\hline Orissa & 70 \\
\hline Punjab & $102.60-104.31$ \\
\hline Rajasthan & $87.81-100.00$ \\
\hline Sikkim & 100 \\
\hline Tamil Nadu & $57.94-158.70$ \\
\hline Tripura & $62.00-98.08$ \\
\hline Uttar Pradesh & $76.31-115.87$ \\
\hline Uttarakhand & $72.22-142.42$ \\
\hline Andaman \& Nicobar & $130.00-161.77$ \\
\hline Chandigarh & 136.4 \\
\hline Dadra \& Nagar Haveli & 102 \\
\hline Daman \& Diu & 95 \\
\hline Delhi & 142 \\
\hline Lakshadweep & 71.9 \\
\hline Puducherry & $55.77-124.00$ \\
\hline
\end{tabular}

Source: Annual report, 2009-10 Ministry of labour and Employment, GOI 


\section{Copyright Disclaimer}

Copyright reserved by the author(s).

This article is an open-access article distributed under the terms and conditions of the CreativeCommons Attribution license (http://creativecommons.org/licenses/by/3.0/). 